\title{
MAN'S GENDER AND AGE AS BASED ON THE COLLOCATIONS OF THE ESTONIAN WORD MEES 'MAN'
}

\section{Liisi Piits}

\begin{abstract}
This study explores collocational patterns of the noun mees 'man' (in comparison with the data found for naine 'woman' and poiss 'boy'), which can reveal social attitudes and stereotypes of age, gender and behaviour. The corpus based study uses the Estonian Reference Corpus (203 million words altogether) where $75 \%$ of the texts are journalistic, so the results will mainly show how people are depicted in the media. Research data was retrieved by means of the Sketch Engine (see Kilgarriff et al. 2004), which enables collocations to be found using lexico-grammatical constructions. Two lexico-grammatical constructions were analysed: the adjectival modifiers of nouns and verbs co-occurring with a noun functioning as a subject.

Differences in the descriptions of men, women and boys as reflected in specific adjectives and verbs are discussed under five themes: man's aggressiveness, man in verbal interaction and his emotions, man in public and private spheres, man's appearance and personality and man as an adult.
\end{abstract}

Keywords: age, adjectives, boy, collocation, Estonian, gender, man, verbs, woman

\section{INTRODUCTION}

As it is generally understood, the semantic process in mother tongue acquisition cannot happen without contextual (general as well as linguistic) support, i.e. an understanding of a word's meaning develops and is fixed in the process of use. If this is the case, the true meaning of a word could perhaps be discovered by an opposite movement from a big text corpus, over collocations, to the word. It has been argued that collocational patterns can reveal social attitudes, particularly with regard to certain stereotypes of age, gender and behaviour (Caldas-Coulthard \& Moon 2010). Thus, we proceed on the assumption that frequent collocational relations enable one to deconstruct latent meanings and analyse how men are (subconsciously) depicted in texts.

The topic of the article is among those discussed in my doctoral dissertation Collocations of the most frequent Estonian words for 'human being' (Piits 2015), 
supervised by professor Urmas Sutrop. The present study, however, is focused on the adjectival modifiers of the word mees 'man' and the verbs for which mees acts as a subject (in comparison with the data found for gender-contrasted naine 'woman' and for age-contrasted poiss 'boy'). Analysis of the adjectival modifiers is expected to demonstrate the typical description of men, while the frequent verb collocates should reveal the activities associated with men as subjects. My main focus is on the collocational relations specific to the word mees 'man', concentrating on those adjectives and verbs whose co-occurence with mees is at least three times higher than with the gender-contrasted naine 'woman' or with the age-contrasted poiss 'boy'. This is expected to reveal the specific traits of age and gender that are attributed to men by the users of the Estonian language. However, despite the spotlight being on differences between men and women or men and boys, one should not forget the huge amount of shared collocates. The word mees 'man' has a thousand adjectival attributes; $36 \%$ of them occur at least once among the attributes of poiss 'boy' as well, while the coincidence between the adjectival attributes of mees 'man' and naine 'woman' is as high as 60\%. For my dissertation I also collected material for words like tüdruk 'girl', poeg 'son', tütar 'daughter', laps 'child' etc. But in this article I focus on collocations of word mees 'man' and collocations of its gender- and age-contrasted antonyms.

The article makes a difference between sex and gender, the former denoting the anatomical and physiological differences between men and women and the latter standing for cultural or learnt differences. Ever since the 1970s when the US anthropologist Gayle Rubin introduced the terminological division, there has been no consensus on the matter. Judith Butler (1990), for example, argues that the notion of biological sex is often culturally determined. According to several scholars, some statements of natural science also have a gendered basis, and, thus, the notion of a binary division of sexes has undergone a historical change (Liljeström 2003: 118). In spite of this, in the present study, a special note will be made if collocates directly depend on the sex of the node word referent, such as, for example, verbs of reproductive functions, like sünnitama 'to give birth', viljastuma 'be fertilised', viljastama 'to fertilise' and rasestama 'to impregnate', or adjectives of fertility, like rase 'pregnant', (last) ootav 'expecting (a baby)' and imetav 'breastfeeding'. And yet, we are more interested in gender reflections in language as language is, to a great extent, where gender is born, where gender roles and stereotypes are reinforced and reproduced. Gender is, after all, defined as an assemblage of stereotypes or people's beliefs about a group and its members. Gender stereotypes are manifested in various aspects of life, such as personality traits, behaviour, professional choices, hobbies, looks, family functioning and various preferences (Huntoon 2009: 378). 
Apart from gender specifics, the second spotlight of the article is on the possible age specifics of men. According to the Estonian Explanatory Dictionary (EKSS 2009), the major sense of the word mees 'man' is meessoost inimene, meesisik, meesterahvas 'male person', from which it could be assumed that mees applies indiscriminately to all age groups. However, sometimes the word could be used as opposed to naine 'woman' or poiss (poisike) 'boy (little boy)'. Opposition to boy as a non-adult should reveal the adult traits and adult activities of men. Although the development from boyhood to adulthood occurs gradually and while its interpretation depends on whether we view it from a religious, socio-cultural or juridical perspective (Panther \& Thornburg 2012: 2), some differences can be expected to manifest.

\section{DATA AND TOOLS}

The linguistic data were collected from the Estonian Reference Corpus maintained by the University of Tartu. Most of the corpus (203 million words altogether) consists of journalistic texts, but texts of fiction, law, chat rooms, web forums and scientific articles are also represented. The fiction texts are not older than the 1990s, and the journalistic texts represent the period from 1995-2008. Journalistic material is collected from daily newspapers Postimees, Päevaleht and Õhtuleht as well as from weekly newspapers Eesti Ekspress, Maaleht and different magazines like Kroonika, Horisont and Eesti Arst. The scientific articles come from 1997-2006. The new media texts were downloaded from the Internet from 2003-2008. For a detailed description of the Reference Corpus, see the homepage at http://www.cl.ut.ee/korpused/segakorpus. As the corpus is not a balanced one, as $75 \%$ of the texts are journalistic, the results will mainly show how people are depicted in the media. According to Barbi Pilvre (2011a), for example, the media has an important role in the development of stereotypes. She notes that, in the media, women tend to be depicted in certain stereotyped roles associated with the private sphere; also, aspects of the female body are often described in personal portraits of the weekly Eesti Ekspress, as well as in other media, when covering women (Pilvre 2011a: 182; Pilvre 2011b). The media in general has been criticised for the advance of a person-centred approach (Nuolijärvi \& Tiittula 2000: 19). As for style, the media tends to be dominated by adult, mostly educated usage. It is not impossible that a higher proportion of fiction or new media texts would have produced different results.

Research data was retrieved by means of the Sketch Engine (see Kilgarriff et al. 2004), which enables collocations to be found using lexico-grammatical 
constructions. The program recognises collocations on the basis of the output of automatic morphological analysis (part of speech plus grammatical features) combined with statistical methods. Evaluators of the Sketch Engine have noted that the quality of the results depends not only on the size and quality of the corpus and the adequacy of morphological analysis but to a considerable extent also on the word sketch grammar used (Kilgarriff et al. 2010: 4).

The present study uses the word sketch grammar devised by Jelena Kallas (Version 1.5, for a detailed survey of the rules see Kallas 2013). The program searches the data for grammatically linked word pairs and ranks them according to their frequency of co-occurrence. Two lexico-grammatical constructions were analysed:

1. The adjectival modifiers of nouns were detected by the rule called Adj_modifier in the Estonian module of the Sketch Engine (see Kallas 2013: 36), which uses part-of-speech labels to pick adjectives of the positive degree of comparison, in whatever case, governed by the following noun in case and number. The use of the adjectival modifiers thus found should be a straight indication of how man is typically described.

2 . The verbs co-occurring with a noun functioning as subject were found by the rule subject_of (see Kallas 2013: 64), which recognises the finite and personal forms of verbs co-occurring with a full subject. The frequent verbs whose subject is mees 'man' show for what activities men are typically described as subjects.

It is true that the rules cannot be expected to recognise all of the relevant cases, and some additional mistakes may occur due to morphological analysis errors and partly inefficient rules (see Piits 2015: 79-80; 103-105), but, as the rules applied are the same for all words, the output adjectives and verbs are comparable enough. Table 1 presents the Corpus frequencies of the words mees 'man', naine 'woman' and poiss 'boy' and the numbers of verbs and adjectival modifiers, together with their percentage of the node word frequency of occurrence. For example, in $14 \%$ of the occurrences, the word mees 'man' co-occurs with and adjectival modifier while, in $17 \%$ of the occurrences, the word mees has the function of a subject. 
Table 1. Corpus frequency of the words mees 'man', naine 'woman' and poiss 'boy' and the number of constructions detected by the Adj_modifier and subject_of rules.

\begin{tabular}{|l|l|l|l|}
\hline $\begin{array}{l}\text { Node } \\
\text { word }\end{array}$ & $\begin{array}{l}\text { Corpus } \\
\text { frequency }\end{array}$ & $\begin{array}{l}\text { No. of adjectival modifiers } \\
\text { and their percentage of } \\
\text { node word frequency }\end{array}$ & $\begin{array}{l}\text { No. of verb constructions } \\
\text { and their percentage of } \\
\text { node word frequency }\end{array}$ \\
\hline $\begin{array}{l}\text { mees } \\
\text { 'man' }\end{array}$ & 307624 & $43922(14.0 \%)$ & $52914(17.2 \%)$ \\
\hline $\begin{array}{l}\text { naine } \\
\text { 'woman' }\end{array}$ & 179449 & $23997(13.0 \%)$ & $26160(14.6 \%)$ \\
\hline $\begin{array}{l}\text { poiss } \\
\text { 'boy' }\end{array}$ & 59315 & $10943(18.0 \%)$ & $10705(18.0 \%)$ \\
\hline
\end{tabular}

Of the three words examined, mees 'man' has the highest Corpus frequency reading, which is 1.7 times higher than that of naine 'woman' and 5.2 times higher than that of poiss 'boy'. The difference between the frequency readings of mees 'man' and naine 'woman' proves the rule that words of male reference are more frequent than those of their female counterparts. A similar tendency has been observed in other languages, such as, for example, English, where the lemma man is 1.5 times more frequent than the lemma woman (Pearce 2008: 2). The fact that poiss 'boy' is several times less frequent than mees 'man' obviously shows that non-adults and their activities are not a particularly important subject for journalistic texts. In order to enable the comparability of the collocation frequencies of node words with different frequencies of occurrence, I computed a normalised co-occurrence rate, indicating the ratio of the frequency of a specific collocate to all other collocations found with the node word in question. The use of normalised co-occurrence levels down the differences conditioned by the incidence differences of the node words (see Biber et al. 1998: 263, 264). In order to avoid accidental results, I left aside all collocates occurring less than four times in every 10000 verb constructions or adjective extensions. Moreover, as the aim of the present study was to shed light on differences, my analysis was only applied to those collocates whose normalised co-occurrence rate with the node word is at least three times higher than with another node word. Detailed data about collocation frequencies of the nouns mees, naine and poiss is accessible in http://hdl.handle.net/10062/45486, where the file Lisa 5 contains the data this article is based on. 


\section{AGGRESSIVE MAN}

In the description of men, adjectives associated with criminal or deviant behaviour are very salient. Adjectives such as kahtlane 'suspicious', sü̈̈distatav 'accused', kahtlustatav 'suspected', vägivaldne 'violent', verine 'bloody' and tundmatu 'unknown' occur much more often among the collocates of mees 'man' than among those of poiss 'boy' or naine 'woman'. Among the collocates of naine 'woman', the word tundmatu 'unknown' is found four times more seldom than with mees 'man'. Curiously, in more than half of the cases, the phrase tundmatu mees 'unknown man' occurs in the descriptions of a perpetrator while $75 \%$ of the uses of tundmatu naine 'unknown woman' apply to a victim. The adjective verine 'bloody' is mostly found in the descriptions of the male victim of a crime or a traffic accident.

Although at first sight the man-specific rääkiv 'speaking' and kõnelev 'speaking' seem indicative of men's overwhelming need of expression, a closer inspection of the concordance lines revealed that these words belong to the description of perpetrators and victims in the police section. In addition, nearly always, these words occur in longer phrases with modifiers of language competence, such as eesti /vene keelt rääkiv / kõnelev 'Estonian/Russian-speaking' (see examples).

\section{Peksjad olid noored eesti keelt rääkivad mehed.}

The beaters were young Estonian-speaking men. (Eesti Päevaleht 13.11.1998)

2. Kaks vene keelt kõnelevat meest on röövinud tänaval relvataolise esemega ähvardades üksikuid naisi.

Two Russian-speaking men have been robbing single women, threatening them in the street with a gun-like object. (SL Õhtuleht 03.10.1999)

In eight cases out of ten, reference is made to Russian speakers while Estonian is mentioned once and so is a third language. Why? The reading cannot be explained just by most of the criminals having a Russian-speaking background (no more but 57\% of Estonian prisoners speak Russian as their mother tongue while 40\% are native speakers of Estonian (Ahven \& Kruusmaa 2013: 104)). The reason should be rather seen in markedness. In Estonia, official Estonian is obviously the norm, not an aberration worthy of verbal marking.

Verb analysis also shows that men are mentioned as subjects of aggressive activities many more times than are women. The verbs vägistama 'rape', tungima 'intrude', kaaperdama 'hijack', tulistama 'shoot', röövima 'rob', pooma 
'hang' and võitlema 'battle; fight', for example, are specific to men. No aggressive verbs specific to women were revealed.

The description of boys implies a similar degree of aggressiveness, but the activities mentioned are different. Non-adult deviant behaviour includes teasing, bullying, fighting, breaking and hijacking, whereas adult men are mentioned as subjects of vägistama 'rape', tungima 'intrude', pussitama 'stab' and petma 'deceive' several times more often than boys.

According to Pearce's analysis of English data (British National Corpus), words associated with crime and offence also collocate more strongly with man than with woman (Pearce 2008: 9). The asymmetry looks reasonable as most of the perpetrators are male. In Estonia, male persons make up 88\% of suspects (Lindsalu 2012: 8) and 95\% of prisoners (Ahven \& Kruusmaa 2013: 103). Most of the victims are also male.

\section{MAN IN VERBAL INTERACTION AND HIS EMOTIONS}

According to Janet Hyde's (2005) gender stereotypic view, women are more emotional and verbally more able than men, although she fails to corroborate her statement with valid empirical proof. In contrast, Hyde presents results to the effect that male/female differences in verbal ability and behaviour are small. We also have no comparative data on the verbal abilities of Estonian men and women, yet a closer look at the 30 most frequent gender-specific collocate verbs of words for 'human being' arranged in antonym pairs, such as mees-naine 'man-woman', isa-ema 'mother-father', poeg-tütar 'son-daughter' and poiss-tüdruk 'boy-girl', reveals that the collocates of words with a female referent include more verbs of interaction than do those with a male referent (Piits 2015). The number of gender-specific verbs thus revealed did not differ within the word pairs. The verbs gender-specific to mees 'man' are käsutama 'command', vaidlustama 'contest', ähvardama 'threaten', vestlema 'converse', muhelema 'chuckle' and pomisema 'mumble'. The first three refer to a verbal act for which the subject has an ability as well as wish to use his power while pomisema 'mumble' is an interaction verb whose subject does not wish to exert an active influence on others, let alone enforce his power. Although the specific verbs of naine 'woman' also include those whose subjects wish to interfere, such as, for example, manitsema 'admonish' and pahandama 'scold', their subjects lack power. In addition, verbs specific to women include nuuksuma 'sob', ahastama 'despair' and karjatama 'scream', which indicate emotions mainly occurring in victims or persons in a powerless position. Besides the verbs of 
emotional interaction, the woman-specific lexis includes a number of other emotionally loaded words, such as, for example, kiljuma 'shriek', ehmuma 'be startled', pelgama 'fear', vihkama 'hate' and ihaldama 'desire', while the word man collocates only with muhelema 'chuckle' (both gender and age specific) and the age-specific vihastama 'get angry'.

Age-specific (compared to boys) interaction verbs include käsutama 'command', vaidlustama 'contend' and süüdistama 'blame', which indicate a power position; in addition, there are kiruma 'curse' and vanduma 'swear' and such adult style activities as vestlema 'converse', nentima 'state' and avaldama 'declare'. Obviously, men converse, state and declare, while boys just talk and say. According to the language data, non-adult activities include dirty talking, bragging and scrounging. The latter of the three is perhaps the clearest indication of the powerless position of the under-aged. Another characteristic feature seen in boys but rarely mentioned in men is emotionality. Thus, the boy-specific verbs include, for example, kilkama 'scream', kisama 'shout', itsitama 'giggle' kallistama 'hug', pabistama 'jitter' and võpatama 'wince'.

Thus, according to the analysis of interaction verbs, adult men are less frequently depicted as subjects of emotional activities than are women or boys while men are mentioned as subjects of verbal activities as frequently as women and several times more often than boys.

\section{MAN IN PUBLIC AND PRIVATE SPHERES}

Men's lower association with the private sphere follows from less importance being attached to their marital status or female connections. Woman-specific adjectival modifiers include vallaline 'single', endine 'ex-', praegune 'current' and üksik 'solitary', but a man's marital status is hardly ever mentioned, i.e. the collocates of mees 'man' do not include any man-specific adjectival modifiers referring to marital status. An additional word mostly referring to a woman's family relationship is uus 'new', but, as the phrase uus mees 'new man' is also frequent, the adjective was not found to be woman-specific. However, an analysis of concordance lines revealed that, with women, new mainly refers to her relationship with a man, whereas, with men, the same word is rather associated with professional challenges. In nine cases out of ten, the phrase uus naine 'new wife' stands for a new mate (see Example 3), whereas uus mees 'new man' is used exactly as frequently in the sense of filling a vacancy (see Example 4). 
3. 'Siis sa pead uue naise võtma,' naljatas Tiina toona. (Eesti Päevaleht 24.10.2000)

'If so, you'll have to get yourself a new wife,' Tiina had said jokingly.

4. Ta värbas sel aastal viis uut meest. (SL Õhtuleht 22.09.2007)

He recruited five new men this year.

Men's closer association with the public sphere is revealed by the words referring to social status and affluence, which make up a large share of man-specific adjectives. Adjectives such as tähtis 'important', rikas 'rich', jõukas 'prosperous', rahvusvaheline 'international' and vaene 'poor' are specific to men from the aspects of gender as well as of age. In addition, we find adult men being described as kuulus 'famous', edukas 'successful', kodutu 'homeless', töötu 'unemployed' and töötav 'working' more often than boys. It is worth noting that the latter word also occurs among the collocates specific to naine 'woman; wife', which means that working is significantly more frequent among the collocates of man than among those of boy, but, in the case of the gender-opposed pair mees-naine 'man/woman', töötav 'working' occurs several times more often with naine 'woman; wife'. This is an interesting finding in view of the assumption that, in Estonian culture, where working is an important part of a man's identity, the phrase töötav mees 'working man' can be expected to occur as often as or even more frequently than töötav naine 'working woman'. A closer analysis of the concordance lines provides an answer to this. With mees, in nine cases out of ten, the collocate töötav belongs to a three-member phrase where töötav mees is modified by a job reference (see Example 5). With naine, the collocate töötav occurs over three times more frequently, but, in half of the cases, there is no job reference, which means that the phrase töötav naine 'working woman' means just an employed woman, i.e. not a housewife (see Example 6). Consequently, women are considered more likely to stay at home, whereas, for men, the employed/stay-at-home opposition is practically inconceivable, which calls for a specification of the man's job or office.

5. Klienditeenindajana töötav mees ei näe asja tumedates toonides ... (Eesti Päevaleht 10.11.2004)

The man working in customer service does not look particularly worried ...

6. Uurimus näitas, et töötavatel naistel oli koduprouadest madalam kolesteroolitase, vererõhk ja kehakaal. (Eesti Päevaleht 25.01.1999)

The research showed that working women had a lower cholesterol level, blood pressure and body weight than housewives. 
No boy-specific adjectives marking social or marital status were revealed. Similarly, according to Baker's findings for English data, men have, through the ages, been described by many words of power and success, such as rich, wealthy, grand, famous and distinguished, which hardly ever appear in female contexts (Baker 2010: 138). Obviously, the gender-specific adjectives reflect what is considered important for either gender. For a woman, it is her relations with a man - ex-wife, new wife or a single woman. In a man's case, his social status comes to the fore - rich or poor, his role in society. Neither specification works for non-adults.

Although modern women's chances to find employment outside the home are almost as good as men's, the post-industrial stereotypes of man as the breadwinner and of woman as the one responsible for housework are slow to change in Europe (Huntoon 2009: 379). Actually, women's entrance to the labour market does not seem to have brought much change to the division of housework. In Estonia, for example, women do twice as much housework as men (Talves 2011: 103). According to gender monitoring conducted in 2009, Estonian women are mainly responsible for laundry and clothing maintenance, cooking, washing up, tidying up etc., whereas men take care of emergencies, such as repair work and car maintenance (Vainu et al. 2010: 123). This division of labour is well reflected in specific verbs. The only man-specific verb is ehitama 'build' (which may mean a home emergency as well as paid employment) while women-specific verbs include pesema 'wash; launder', kuduma 'knit' and omblema 'sew'.

In addition to general housework, women with kids usually communicate with kindergarten and school, play with children, help them and provide transport (Vainu et al. 2010: 123). This is reflected in the woman-specific verbs kasvatama 'rear' and toitma 'feed', as well as in the adjectival modifiers kasvatav '(child)rearing' and kodune 'stay-at-home'. In addition, woman-specific collocates include the verbs rasestuma 'to become pregnant' and sünnitama 'give birth', which signify reproductive functions, and the adjectives rase 'pregnant', sünnitav 'delivering', (last) ootav 'expecting (a child)', viljatu 'sterile' and imetav 'breastfeeding', which are associated with fertility. The analysis shows that, first and foremost, these collocates all have to do with biological sex. Men's most frequent collocates did not include verbs or adjectives associated with biological sex or fertility. 


\section{MAN'S APPEARANCE AND PERSONALITY}

Descriptions of men's appearance stand out for the use of the adjectives must 'black', turske 'sturdy' and verine 'bloody', which are not found among the collocates of women or boys. Of these three, verine 'bloody' belongs to crime statistics, but the former two do not, in most cases at least. The adjective must 'black', which mainly signifies racial affiliation, usually occurs in descriptions of musicians, sportsmen, etc. As can be seen from the examples below, the word need not mean the darkest possible skin colour.

7. See on must mees, pakistanlane, ta ei tohi minna, ära teda sisse lase! (Eesti Päevaleht 03.12.2005)

This is a black man, a Pakistani, he can't go through, don't let him in!

\section{Belgradi jaama ümbruses tiirleb musti mehi nagu kärbseid. (Areen 1998)}

Black men are crowding around the Belgrade railway station like flies.

Although the Estonian word must may mean not only 'black' but also 'dirty, unclean' (see EKSS 2009), in the corpus analysed, the collocation must mees 'black man' did not reveal any uses of the latter sense. In addition, men and not boys are described in this data as mustanahaline 'black-skinned' or valge 'white'. Moreover, adult men are sometimes described as hallipäine 'grey-haired'. In comparison with women, men's bulk is emphasized by using adjectives such as turske 'sturdy', suur 'big' and (...kg) kaaluv 'weighing (... kg)' while the collocates of naine 'woman; wife' include, besides ülekaaluline 'overweight', several words underlying their fragility and vulnerability, such as habras 'delicate', sale 'slim' and blond 'blonde'.

The analysis of gender-specific adjectives showed that attractiveness or its absence is seldom emphasized in men, whereas women are described as being kaunis 'beautiful', ilus 'pretty', naiselik 'womanly' or inetu 'plain, ugly' several times more often. The frequent adjectives of attractiveness, such as ilus 'pretty', kaunis 'beautiful' and kena 'nice', constitute less than $1 \%$ of all adjectives modifying the word mees 'man', in comparison to the over 5\% reading for naine 'woman' (Piits 2015: 129). Hence, the conclusion that, Estonian descriptions of men's external beauty is an insignificant issue mentioned several times more seldom than in the case of women. However, the word ilus 'pretty; handsome' does belong to the 30 most frequent adjectival collocates of both poiss 'boy' and mees 'man' (ibid.: 124). Paul Baker, in his diachronic study of the collocations of man, has found that, compared to English in the previous century, there is 
a growing tendency of describing men as pretty, dapper and handsome (Baker 2010: 138), words which directly refer to attractiveness. There are no comparable diachronic studies as yet for Estonian. Nudity is also mentioned rarely with men; the word paljas 'naked', for example, occurs four times more often with naine 'woman' than with mees 'man'. A man is never described as a sexual object; rather, his racial affiliation or bulk is pointed out.

A man's personality, psyche and behaviour are described in much more detail than his physique. The negative traits mentioned include vihane 'angry', karm 'rough', kahtlane 'suspicious' and vägivaldne 'violent'. General negative evaluation is expressed by the word vale 'wrong'. Positive man-specific personality traits and general evaluatives from both gender and age aspects are aus 'honest', õige 'right', vajalik 'necessary', mõistlik 'reasonable' and mõnus 'cool'. The meaning of the adjective aus 'honest' differs depending on whether it refers to a man or woman. Aus mees signifies a morally virtuous person (see example 9 ) while the few cases of aus naine refer rather to a sexually virtuous woman with strict moral standards (see Example 10):

9. Ta on väga aus mees. Ta ütles, et ei taha valetada. (Eesti Päevaleht 18.03.2006)

He is a most honest man. He says he doesn't want to lie.

10. Ma ei kujuta üldse ette, kuidas üks aus naine suudab rõõmu tunda selliste võltside vahendite abil saavutatud seksuaalvahekorrast! (Eesti Päevaleht 10.03.2001)

I can't imagine how an honest woman could enjoy sexual intercourse achieved by such fake means!

Age-specific adjectives describing man also include tark 'clever; wise', tõeline 'real', kange 'efficient' and onnelik 'happy'. Thus, wisdom, efficiency and happiness are associated with adulthood while persons under age evoke such attributes as talented, naughty and cute. The words kovva 'tough', tore 'nice' and asjalik 'no-nonsense', however, are used independently of the age of the male person. 


\section{MAN AS AN ADULT}

The biggest group of age-specific adjectives for men defines their age. Most of the adjectives end in aastane '... years old' while keskealine 'middle-aged', eakas 'elderly' and vana 'old' specify age less definitely and more subjectively. Although mees is applicable to all age groups, exact specifications invariably refer to persons aged 18 or older, whereas the exact specifications of poiss refer to boys under 18. '18-year-old' is the only exact age attribute used with mees as well as with poiss; in all other cases where aastane is used, a clear difference is made.

Power in the family largely depends on who decides how family money should be used. According to resource theory, the power balance tilts in favour of the party who contributes more to the family's income (Talves 2011: 111). The adjectives referring to man's affluence show that the husband is mostly assumed to be the main contributor while power lines need not run between different sexes at all. Man occurs as the subject of the verb maksma 'pay' several times more often than is the case for boy. Lack of power in the case of non-adults is reflected in the verbs kuuletuma 'obey', imetlema 'admire' and järgima 'follow' collocating with poiss 'boy'. Violence and criminal behaviour have also been interpreted as demonstrations of power. However, here, my method fails to reveal major differences because various aggressive activities are mentioned in connection with men as well as boys, although the activities differ.

A comparison with boy-specific verbs enables the conclusion that learning and acquisition, as well as certain creative activities like handicrafts, drawing, singing and dancing, do not belong to adult activities.

\section{CONCLUSION}

This article is focused on differences in Estonian media descriptions of men, women and boys as reflected in specific adjectives and verbs. It is true that there are also great similarities in the collocational behaviour of the words in question. For example, comparing the lists of the 30 most frequent verbs belonging to the words mees 'man', naine 'woman' and poiss 'boy', we find that two thirds of them coincide (Piits 2015: 106-107). And yet, the differences are eloquent enough to reveal how, in comparison with boys and women, the Estonian-language media describes men's appearance and personality, their peculiarities of verbal expression and their activities in the private and public spheres.

According to my analysis of interaction verbs, adult men are less frequently presented as subjects of various emotional activities than are women or boys 
while man functions as the subject of various verbal activities as often as woman and several times more often than boy. Man-specific interaction implies a power position; man orders and commands, contends and blames.

Violence and criminal behaviour have also been interpreted as a demonstration of power. Descriptions of men are conspicuous for adjectives associated with criminal or deviant behaviour, especially in comparison with women, while boys also engage in aggressive and deviant activities.

Unlike woman, man is not described as a sex object; instead, his physical aspect is marked by mentioning his race and bulk. Man's physique is described in far less detail than his personality, psyche and behaviour. Man is usually seen as active in public life, and his private sphere is less in focus. His social status is important, his being rich or poor, as is his role in society.

\section{ACKNOWLEDGEMENTS}

This work was supported by institutional research funding IUT 35-1 of the Estonian Ministry of Education and Research, TK145 "Centre of Excellence in Estonian Studies - CEES", and the governmental basic financing of the Institute of the Estonian Language from the Estonian Ministry of Education and Research.

\section{REFERENCES}

Ahven, Andri \& Kruusmaa, Kätlin-Chris 2013. Vangistus ja kriminaalhooldus: Kuritegevus Eestis 2012. [Imprisonment and Probation: Criminal Activity in Estonia 2012.] Tallinn: Justiitsministeerium.

Baker, Paul 2010. Will Ms Ever Be as Frequent as Mr? A Corpus-Based Comparison of Gendered Terms across Four Diachronic Corpora of British English. Gender and Language, Vol. 4, No. 1, pp. 125-149. DOI: 10.1558/genl.v4i1.125.

Biber, Douglas \& Conrad, Susan \& Reppen, Randi 1998. Corpus Linguistics: Investigating Language Structure and Use. Cambridge: Cambridge University Press.

Butler, Judith 1990. Gender Trouble: Feminism and the Subversion of Identity. New York \& London: Routledge.

Caldas-Coulthard, Carmen Rosa \& Moon, Rosamund 2010. 'Curvy, Hunky, Kinky': Using Corpora as Tools for Critical Analysis. Discourse \& Society, Vol. 21, No. 2 , pp. 99-133. DOI:10.1177/0957926509353843.

EKSS $2009=$ Eesti keele seletav sõnaraamat I-VI. [The Explanatory Dictionary of Estonian I-VI.] Tallinn: Eesti Keele Sihtasutus. 
Huntoon, Alishia 2009. Gender Stereotypes. In: Jodi O’Brien (ed.) Encyclopedia of Gender and Society 2. California: SAGE Publications. http://dx.doi. org/10.4135/9781412964517.n189.

Hyde, Janet Shibley 2005. The Gender Similarities Hypothesis. American Psychologist, Vol. 60, No. 6, pp. 581-592. http://dx.doi.org/10.1037/0003-066X.60.6.581.

Kallas, Jelena 2013. Eesti keele sisusõnade süntagmaatilised suhted korpus- ja õppeleksikograafias. [Syntagmatic Relationships of Estonian Content Words in Corpus and Pedagogical Lexicography.] Tallinn: Tallinna Ülikool.

Kilgarriff, Adam \& Rychly, Pavel \& Smrz, Pavel \& Tugwell, David 2004. The Sketch Engine. In: G. Williams \& S. Vessier (eds.) Proceedings of the 11th EURALEX International Congress. Lorient: Université de Bretagne Sud, pp. 105-115. Available at http://www.euralex.org/proceedings-toc/euralex_2004/, last accessed on May 23, 2106.

Kilgarriff, Adam \& Kovar, Vojtech \& Krek, Simon \& Srdanovic, Irena \& Tiberius, Carole 2010. A quantitative evaluation of word sketches. Proceedings Euralex. Leeuwarden, The Netherlands: Euralex, pp. 372-379. Available at http://www. euralex.org/proceedings-toc/euralex_2010/, last accessed on May 23, 2016.

Liljeström, Marianne 2003. Soosüsteem. [Gender System.] In: A. Koivunen \& M. Liljeström (eds.) Võtmesõnad. [Keywords.] Tallinn: Eesti Keele Sihtasutus.

Lindsalu, Pilleriin 2012. Kuritegevus Eestis 2011. aastal: kokkuvõte. [Crime in Estonia 2011: Summary.] Kuritegevus Eestis 2011. [Crime in Estonia 2011.] Tallinn: Justiitsministeerium.

Nuolijärvi, Pirkko \& Tiittula, Liisa 2000. Televisiokeskustelun näyttämöllä: televisioinstitutionaalisuus suomalaisessa ja saksalaisessa keskustelukulttuurissa. [Television Discussion Stage: TV-institution in Finnish and German Conversation Culture.] Helsinki: Suomalaisen Kirjallisuuden Seura.

Panther, Klaus-Uwe \& Thornburg, Linda L. 2012. Antonymy in Language Structure and Use. In: Mario Brdar \& Milena Žic Fuchs \& Ida Raffaelli (eds.) Cognitive Linguistics between Universality and Variation. Newcastle, UK: Cambridge Scholars, pp. 161-188.

Pearce, Michael 2008. Investigating the Collocational Behaviour of MAN and WOMAN in the BNC Using Sketch Engine. Corpora, Vol. 3, No. 1, pp. 1-29. DOI: 10.3366/ E174950320800004X.

Piits; Liisi 2015. Sagedamate inimest tähistavate sõnade kollokatsioonid eesti keeles. [Collocations of the Most Frequent Estonian Words for 'Human Being'.] Tartu: Tartu Ülikooli Kirjastus.

Pilvre, Barbi 2011a. Meedia ja sugu. [Media and Gender.] In: Raili Marling (ed.) Sissejuhatus soouuringutesse. [Introduction to Gender Studies.] Tartu: Tartu Ülikooli Kirjastus.

Pilvre, Barbi 2011b. Naiste meediarepresentatsioon Eesti ajakirjanduskultuuri ja ühiskonna kontekstis. [Media Representation of Women in the Context of Estonian Journalist Culture and Society.] Tartu: Tartu Ülikooli Kirjastus.

Talves, Kairi 2011. Soosotsioloogia. [Sociology of Gender.] In: Raili Marling (ed.) Sissejuhatus soouuringutesse. [Introduction to Gender Studies.] Tartu: Tartu Ülikooli Kirjastus. 
Vainu, Vaike \& Järviste, Liina \& Biin, Helen 2010. Soolise võrdõiguslikkuse monitooring 2009. [Studies of Gender Equalities 2009.] Sotsiaalministeeriumi toimetised 1. Tallinn: AS Ecoprint. 